\title{
Mast cells in parathyroid glands of hyperparathyroidism
}

\author{
T. J. ANDERSON \\ From the Department of Pathology, University of Aberdeen
}

SYNOPSIS Parathyroid glands from cases of hyperparathyroidism have been examined with particular attention to mast cells. In 'normal' glands accompanying an adenoma they were common, although there was a wide range in their frequency, whereas in pathological tissue, both adenoma and hyperplasia, mast cells were scarce. This difference between glands was examined with respect to alterations in gland size, to variations in the amount of interstitial tissue, to degrees of overactivity, and to anatomical development of the glands. No conclusions can be drawn with regard to the significance of mast cells in parathyroid tissue.

Since the recognition of primary chief cell hyperplasia as an entity (Cope, Keynes, Roth, and Castleman, 1958) the clear differentiation between adenoma and hyperplasia in some cases of hyperparathyroidism is generally acknowledged to be difficult. This occurs because of the inability to establish clear limits of histological normality in relation to function of parathyroid tissue. Comparative studies of normal and hyperactive human parathyroid tissue (Roth and Munger, 1962; Weymouth and Sheridan, 1966; Black, 1969; Faccini, 1970) have concentrated on histological and ultrastructural differences in the parenchymal cell forms. The mast cell, which was noted in parathyroid glands by Erdheim (1903) and described in the histology of normal human parathyroids (Morgan, 1936; Gilmour, 1939), has not been the subject of a compa rative study. Particular attention has been given, therefore, to mast cells in parathyroidectomy material submitted between 1962 and 1972 to the Department of Pathology, Aberdeen Royal Infirmary. The opportunity to compare pathological and nonpathological tissue arises because of the routine surgical practice to examine histologically all glands identified at exploration. A quantitative analysis for mast cells has demonstrated a difference between glands which is discussed in this paper.

\section{Materials and Methods}

\section{CASE SELECTION}

Material from 56 cases of parathyroid exploration was reviewed (table I). All cases had undergone Received for publication 23 October 1973.
Number of cases reviewed

Adenoma

Hyperplasia

${ }^{1}$ Uncertain but pathological

Table I Histological diagnosis in cases of hyperparathyroidism

Includes cases with only one gland.

exploration as examples of primary hyperparathyroidism except one case of hyperplasia secondary to phosphaturic nephropathy. In $\mathbf{4 0}$ cases with three or more glands a definitive diagnosis of adenoma or hyperplasia was made according to the criteria of table II, and in 29 of these suitable material was available for further study. The separate categories into which the tissue from these cases was placed are given in table III.

\begin{tabular}{lll}
\hline & Adenoma & Hyperplasia \\
\hline $\begin{array}{l}\text { No. of abnormal glands } \\
\text { No. of nodules per gland } \\
\text { Peripheral rim 'normal' }\end{array}$ & $\begin{array}{l}\text { Usually only 1 } \\
\text { Usually only 1 }\end{array}$ & $\begin{array}{l}\text { All } \\
\text { Present }\end{array}$ \\
$\begin{array}{l}\text { Cell pleomorphism more than 1 } \\
\text { Cell type }\end{array}$ & $\begin{array}{l}\text { Present } \\
\text { Uniform }\end{array}$ & $\begin{array}{l}\text { Not marked } \\
\text { Often variable }\end{array}$ \\
\hline
\end{tabular}

Table II Criteria for separation of adenoma from hyperplasia

METACHROMATIC STAINS

Routine paraffin blocks were used to prepare three step sections of each gland to be stained for mast cells with Azure A according to Hughesdon (1949). This method, which permits permanently mounted 


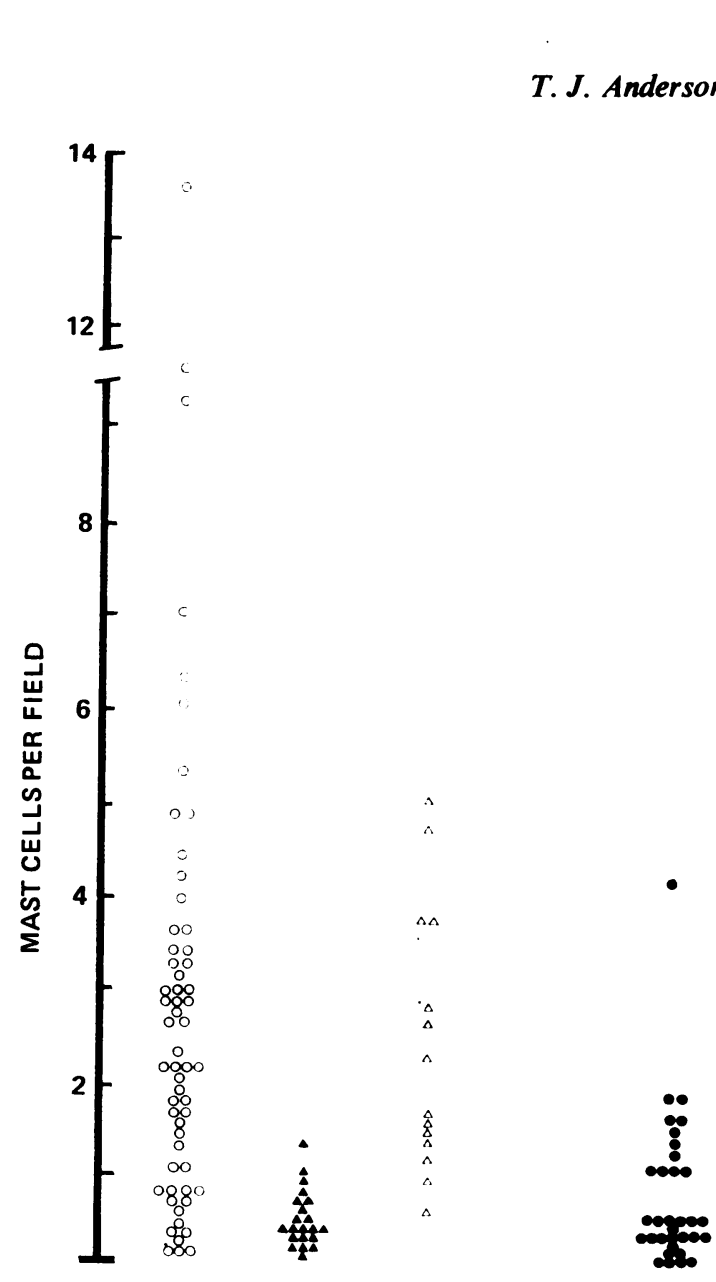

\begin{tabular}{lll}
\hline Categories of Tissue & No. Cases & No. Samples \\
\hline Adenoma & 21 & 21 \\
'Normal' rim adjacent to adenoma & 11 & 11 \\
'Normal' gland accompanying & 21 & 58 \\
adenoma & 8 & 32 \\
Hyperplasia & 8 & \\
\hline
\end{tabular}

Table III Histological classification of tissue samples

specimens, was shown by preliminary investigation to give the clearest and most consistent definition of metachromatic cells.

\section{COUNTING PROCEDURE}

Sections were scanned ( $\times 25$ objective, 54 micrometre field diameter) and a record was kept of the number of fields screened together with the number of mast cells encountered. A positive score was recorded only where metachromatic granules were associated with a nucleus. Although preliminary analysis of five cases (17 glands) showed no significant difference between each level of the same gland, all levels of all glands were assessed to increase the number of observations for the smallest glands. For 'normal' glands the entire section was screened, whilst for large pathological glands the assessment was restricted to 100 fields, comprising 50 peripheral (one field width from the edge) and 50 central fields. The figures were used to calculate a value of mast cell density per unit area per gland.

In the same manner, a standard point counting procedure was used to estimate the amounts of interstitial tissue, including fat, in 'normal' glands.

\section{Results}

\section{ALL GLANDS}

Mast cells were observed in the situations described previously (Morgan, 1936; Gilmour, 1939), namely, in the interstitial tissue spaces, often in proximity to arterioles and venules, and also adjacent to fat spaces. Less frequently they were present within parenchymal cell aggregates, where they could be in relation to any of the parenchymal cells, whether chief, water clear, or oxyphil in type. The average number $( \pm$ SEM) of mast cells observed per gland was $162 \pm 14$ and of fields examined per gland was $142 \pm 10$.

COMPARISON: NORMAL AND PATHOLOGICAL The results of the analysis are shown in fig 1 where the value for each gland is recorded according to the categories of table III. Mast cells were infrequent in pathological tissue, both adenoma and hyperplasia. In comparison, the number in 'normal'
Fig Mast cells in parathyroid glands in hyperparathyroidism.

$\bigcirc$ 'Normal' gland accompanying adenoma

$\triangle$ 'Normal' rim adjacent to adenoma

$\Delta$ Adenoma

Hyperplasia

tissue, whether present as a 'rim' adjacent to an adenoma or as a separate gland, was greater and in each instance the difference from pathological tissue was highly significant $(P<0.001)$.

Also, a comparison between pathological and 'normal' tissue was made with respect to the distribution of mast cells by site. The ratio of peripheral and central mast cell values for glands in each classified group is given in table IV. A peripheral localization of mast cells predominates in pathological tissue, either adenoma or hyperplasia, which differs highly significantly ( $<<0.001$ ) from 'normal'.

VARIATION OF NORMAL GLANDS

The mast cell values amongst these 'normal' glands 


\begin{tabular}{ll}
\hline $\begin{array}{l}\text { Histological Diagnosis } \\
\text { (No. of Glands) }\end{array}$ & $\begin{array}{l}\text { Mast Cells per Field Ratio: } \\
\text { Periphery }\end{array}$ \\
\hline 'Normal' Centre $( \pm$ SEM)
\end{tabular}

Table IV Comparison of mast cell distribution by site

showed a considerable range which overlapped with that of pathological tissue. Indeed, in two adenoma cases all 'normal' tissue showed values within the 'adenoma' range. In the examination of this difference between glands consideration was given to four variables: the degree of pathological tissue overactivity; variation in amount of interstitial tissue; difference in 'normal' gland size; anatomical relationship of glands.

Serum parathormone levels were not assayed in these cases, but less precise indices of activity are given by the level of hypercalcaemia and by the weight of pathological tissue. In 11 cases an immediate preoperative serum calcium was available (corrected for total serum protein) and in five cases there was a record of accurate gland weights. In neither instance was any correlation demonstrated between these estimates and mast cell density in 'normal' glands (highest or average value).

In 25 'normal' glands from nine cases, taken over the observed range of mast cell values, the amount of interstitial tissue varied from 15 to $75 \%$. Also, an approximation of gland biopsy size was estimated from the total area of sections. However, in neither instance was any correlation evident when mast cell values were plotted as a function of these estimates.

Table $\mathrm{V}$ gives the values for mast cells in glands of the adenoma cases for which tissue from three 'normal' glands was submitted. They are arranged to accentuate the unusual distribution of mast cells amongst the glands. In most cases two 'normal' glands showed numbers which approximated, whilst the third had almost twice as many mast cells. Tests of significance for this observation have not proved practicable. However, because of the embryological relationship between glands as pairs, the anatomical relationship between the adenoma and its corresponding gland with the highest value was examined by reference to the pathological records. No consistent pattern of anatomical relationship was displayed.

\section{Discussion}

It is clear from the results of this analysis that a difference exists with respect to the number of mast cells in sections of parathyroid glands from cases of hyperparathyroidism. Yet the difference is not

\begin{tabular}{|c|c|c|c|c|}
\hline \multirow[t]{3}{*}{ Case No. } & \multicolumn{4}{|c|}{$\begin{array}{l}\text { Mast Cells per Field in Adenomas with Values of the } \\
\text { Accompanying Gland Arranged in Order of Ascending } \\
\text { Frequency }\end{array}$} \\
\hline & \multirow{2}{*}{$\begin{array}{l}\text { Pathological } \\
\text { Adenoma }\end{array}$} & \multicolumn{3}{|l|}{ 'Normal' } \\
\hline & & 1 & 2 & 3 \\
\hline 1 & 1.00 & 2.93 & 3.42 & $5 \cdot 22$ \\
\hline 2 & 0.69 & 0.69 & 1.04 & $2 \cdot 28$ \\
\hline 3 & 0.44 & 0.33 & 0.71 & 1.73 \\
\hline 4 & 0.09 & 1.97 & 3.62 & 13.46 \\
\hline 5 & 0.11 & 0.07 & 0.11 & 1.90 \\
\hline 6 & $0 \cdot 16$ & $0 \cdot 13$ & 0.31 & 0.97 \\
\hline 7 & 0.37 & 0.50 & 0.67 & 1.87 \\
\hline 8 & 0.25 & $2 \cdot 16$ & $2 \cdot 82$ & $4 \cdot 33$ \\
\hline 9 & 0.25 & 0.39 & 0.63 & 0.66 \\
\hline 10 & 0.59 & $2 \cdot 70$ & $2 \cdot 81$ & $6 \cdot 37$ \\
\hline 11 & 0.91 & $4 \cdot 83$ & $4 \cdot 88$ & 6.98 \\
\hline 12 & 0.82 & 1.53 & 2.91 & 5.98 \\
\hline 13 & 1.25 & 0.21 & $2 \cdot 16$ & $4 \cdot 14$ \\
\hline 14 & $0 \cdot 18$ & 3.43 & 3.86 & 9.62 \\
\hline 15 & 0.33 & 1.44 & 2.80 & 3.60 \\
\hline 16 & 0.56 & $1 \cdot 26$ & $3 \cdot 33$ & $9 \cdot 28$ \\
\hline $\begin{array}{l}\text { Mean } \\
( \pm \text { SEM })\end{array}$ & $0.50 \pm 0.09$ & $1.53 \pm 0.34$ & $2.25 \pm 0.37$ & $4.90 \pm 0.90$ \\
\hline
\end{tabular}

Table V Mast cell values of different glands in cases of adenoma

absolute (fig 1, table IV) and it cannot be concluded that the mast cell patterns in the glands is characteristic according to histopathological diagnosis or even that it allows clear distinction between adenoma and hyperplasia. No explanation can be given for those adenoma cases for which all glands gave mast cell values within the general pathological range (less than 2 per field, table V). Nevertheless in the present state of uncertainty regarding the pathogenesis of primary hyperparathyroidism any factor which permits separate classification of cases deserves attention. Furthermore, these observations may have practical value to the pathologist requested to distinguish between adenoma and hyperplasia on the basis of light microscope examination of limited tissue samples, since a gland showing more than two mast cells per field (as defined) is unlikely to be pathological.

The difference between glands that has been demonstrated here raises two issues. Why are mast cells less frequent in pathological tissue; conversely, why does the frequency of their occurrence in 'normal' glands extend over such a range? It should be emphasized that alterations in three-dimensional structure have not been allowed for in the present comparisons of mast cell numbers. Although the results of table IV could be interpreted to indicate change in distribution due to expansile growth of tissue there was no evidence to support this from analysis of other data. Furthermore, despite the inaccuracies of the present estimates of gland size from a biopsy, there is no indication that differences 
in amounts of interstitial tissue account for the variation amongst 'normal' glands, thus making it unlikely that the infrequency of mast cells in pathological tissue can be explained on the basis of lack of interstitial tissue in these glands. Also there is no evidence from the present study that mast cells provide an index of relationship between glands on the basis of development or activity. The role of mast cells in parathyroid glands is not understood.

In the context of mast cells and endocrine tissue, experimental animal studies (Clayton and Szego, 1967; Clayton and Masuoka, 1968; Melander and Sundler, 1972) have associated thyroid mast cell changes with alterations in thyroid hormone secretion in response to trophic hormone stimulation (TSH). However, species differences in characteristics of mast cell ultrastructure and amine precursor metabolism (Nunez and Gershon, 1973) have introduced doubts about the general applicability of these experiments to the human situation.

Despite these dissimilarities, emphasis may still be given to the association between mast cells and tissue stimulation by a trophic factor. Such an association requires investigation in other paired endocrine organs, such as the adrenal glands. Although no trophic substance has been demonstrated for the parathyroids, such a possibility requires re-examination, more particularly in view of the controversy over the proposed interrelationships between the parathyroids and kidneys in the regulation of vitamin D metabolism (Garabedian, Holick, DeLuca, and Boyle, 1972; Larkins, MacAuley, Colston, Evans, Galante, and MacIntyre, 1973).

A quantitative analysis of mast cells in parathyroid glands of hyperparathyroidism has demonstrated a significant difference between pathological and non-pathological tissue. However, clear discrimination between adenoma and hyperplasia has not been achieved, and no satisfactory explanation has been found to account for the variation between the non-pathological glands. An investigation of necropsy material is in progress to determine the $\mathrm{\sigma}$ distribution and variation of mast cell numbers in $\Rightarrow$ parathyroid glands of cases without evidence of $\stackrel{?}{+}$ altered calcium metabolism.

Acknowledgement for statistical analysis is given to $\frac{\overline{\bar{p}}}{\vec{D}}$ Dr G. Hems. I wish to thank Professor A. L.@ Stalker for helpful criticism.

References

Black, W. C., III. (1969). Correlative light and electron microscopy $\vec{\omega}$ in primary hyperparathyroidism. Arch. Path., 88, 225-241.

Clayton, J. A., and Masuoka, D. T. (1968). TSH-induced mobilisation of serotonin from perivascular mast cells in the rat thyroid. Endocrinology, 83, 263-271.

Clayton, J. A., and Szego, C. M. (1967). Depletion of rat thyroid. serotonin accompanied by increased blood flow as an acute. response to thyroid stimulating hormone. Endocrinology, 80, $\omega$ 689-698.

Cope, O., Keynes, W. M., Roth, S. I., and Castleman, B. (1958). 읙 Primary chief cell hyperplasia of the parathyroid glands. Ann. Surg., 148, 375-388.

Erdheim, J. (1903). Zur normalen und pathologischen Histologie der Glandula thyreoidea, Parathyreoidea und Hypophysis. Beitr. path. Anat., 33, 158-236.

Faccini, J. M. (1970). The ultrastructure of parathyroid glands removed from patients with primary hyperparathyroidism: a report of 40 cases, including four carcinomata. J. Path., 102, $\Theta$ 189-199.

Garabedian, M., Holick, M. F., DeLuca, H. F., and Boyle, I. T. (1972). Control of 25-hydroxycholecalciferol metabolism by parathyroid glands. Proc. nat. Acad. Sci. (Wash.), 69, 16731676.

Gilmour, J. R. (1939). The normal histology of the parathyroid glands. J. Path. Bact., 48, 187-222.

Hughesdon, P. E. (1949). Two uses of uranyl nitrate. J. roy. micr. Soc. 69, 1-8.

Larkins, R. G., MacAuley, S. J., Colston, K. W. Evans, I. M. A., Galante, L. S., and MacIntyre, I. (1973). Regulation of vitamin $\bar{O}$ D metabolism without parathyroid hormone, Lancet, 2, 289. 291.

Melander, A., and Sundler, F. (1972). Significance of thyroid mast cell, in thyroid hormone secretion. Endocrinology, 90, 802-807. Morgan, J. R. E. (1936). The parathyroid glands. Arch. Path., 21,

Nunez, E. A., and Gershon, M. D. (1973). Species differences in mast cells of the thyroid gland. Endocrinolozy, 92, 152-159.

Roth, S. I., and Munger, B. L. (1962). The cytology of the adenomatous, atrophic and hyperplastic parathyroid glands of man: a light- and electron-microscopic study. Virchows. Arch. path. Anat., 335, 389-410.

Weymouth, R. J., and Sheridan, M. N. (1966). Fine structure of human parathyroid glands: normal and pathological. Acta. endocr. (Kbh.), 53, 529-546. 